Вопросы языкознания 2013-2023

ISSN 2079-8784

URL - $\underline{\text { http://ras.jes.su }}$

Все права защищены

Номер 6 Том . 2018

\title{
P. Lane, J. Costa, H. De Korne (eds.). Standardizing minority languages: Competing ideologies of authority and authenticity in the global periphery. New York, London: Routledge, 2018
}

\section{Вахтин Николай Борисович}

Европейский университет в Санкт-Петербурге

Институт лингвистических исследований РАН

Российская Федерачия, Санкт-Петербург

Аннотация

Ключевые слова:

Дата публикации: 26.11.2018

Ссылка для цитирования:

Вахтин Н. Б. Р. Lane, J. Costa, Н. De Korne (eds.). Standardizing minority languages: Competing ideologies of authority and authenticity in the global periphery. New York, London: Routledge, 2018 // Вопросы языкознания - 2018. - Номер 6 C. 157-164 [Электронный pecypc]. URL: http://ras.jes.su/vopjaz/s207987840001251-5-1 (дата обращения: 26.04.2023). DOI: 10.31857/S0373658X0002027-8

1 [Рец. на: / Review of:] P. Lane, J. Costa, H. De Korne (eds.). Standardizing minority languages: Competing ideologies of authority and authenticity in the global periphery. New York, London: Routledge, 2018. viii + 249 pp. ISBN 978-1-138-125124. 


\section{Библиография:}

1. Кошкарева 2013 - Кошкарева Н. Б. Актуальные вопросы совершенствования хантыйской графики и орфографии // Вестник угроведения. 2013. № 3 (14). С. 47 78.

2. Gal 2006 - Gal S. Contradictions of standard language in Europe: Implications for the study of practices and publics. Social Anthropology. 2006. No. 14 (2). Pp. 163-181.

3. Irvine, Gal 2000 - Irvine J. T., Gal S. Language ideology and linguistic differentiation. Regimes of language. P. Kroskrity (ed.). Santa Fe (NM): School for American Research, 2000. Pp. 35-84.

4. Silverstein 2003 - Silverstein M. Indexical order and the dialectics of sociolinguistic life. Language and Communication. 2003. No. 23. Pp. 193-229.

5. Woolard 1998 - Woolard K. Introduction: Language ideology as a field of inquiry. Language ideologies: Practice and theory. Schieffelin B, Woolard K., Kroskrity P. (eds.). New York: Oxford Univ. Press, 1998. Pp. 3-50.

6. Woolard 2008 - Woolard K. Language and identity choice in Catalonia : The interplay of contrasting ideologies of linguistic authority. Lengua, nación e identidad: La regulación del plurilingüismo en España y América Latina. Süselbeck K., Mühlschlegel U., Masson P. (eds.). Madrid: Iberoamericana; Frankfurt am Main: Vervuert, 2008. Pp. 303-323. 


\title{
P. Lane, J. Costa, H. De Korne (eds.). Standardizing minority languages: Competing ideologies of authority and authenticity in the global periphery. New York, London: Routledge, 2018
}

\author{
Nikolay Vakhtin \\ European University at St. Petersburg \\ Institute for Linguistic Studies, Russian Academy of Sciences \\ Russian Federation, St. Petersburg \\ Abstract
}

Keywords:

Publication date: 26.11 .2018

Citation link:

Vakhtin N. P. Lane, J. Costa, H. De Korne (eds.). Standardizing minority languages: Competing ideologies of authority and authenticity in the global periphery. New York, London: Routledge, 2018 // Voprosy Jazykoznanija - 2018. - Issue 6 C. 157-164 [Electronic resource]. URL: http://ras.jes.su/vopjaz/s207987840001251-5-1 (circulation date: 26.04.2023). DOI: 10.31857/S0373658X0002027-8

Код пользователя: 0; Дата выгрузки: 26.04.2023; URL - http://ras.jes.su/vopjaz/s207987840001251-5-1 Bce права защищены. 